\title{
A CRÍTICA DA MODERNIDADE: BREVES REFLEXÕES DE ANTHONY GIDDENS, IMMANUEL WALLERSTEIN, DAVID HARVEY, MILTON SANTOS E EDGAR MORIN
}

Cláudio Tadeu Cardoso Fernandes ${ }^{1}$

\begin{abstract}
Antes de chegarmos a uma abordagem sobre a "crítica da modernidade", cuja discussão envolve suas consequiências e contradições, faz-se necessário um esforço de compreensão, a partir de Giddens, do que vem a ser a própria "modernidade", buscando-se também comparações com as idéias de alguns outros autores que tratam do tema. Utilizamos aqui a expressão "esforço de compreensão" pelo fato de que nem sempre há muita clareza sobre o que é a "modernidade" na literatura corrente, onde ocorrem sensíveis diferenças de percepção entre alguns autores, principalmente quanto a uma situação no espaço e no tempo, havendo mesmo quem argumente que já teríamos chegado a uma "pós-modernidade".

Giddens (1991) nos convida a identificar as descontinuidades que separam as instituições sociais "modernas" das ordens sociais "tradicionais". Buscando uma primeira aproximação, o autor diz que a modernidade "refere-se a estilo, costume de vida ou organização social que emergiram na Europa a partir do século XVII e que ulteriormente se tornaram mais ou menos mundiais em sua influência". Para ele, isto associa a modernidade a um período de tempo e a uma localização geográfica inicial, "mas por enquanto deixa suas características principais guardadas em segurança numa caixa preta". Em trabalho mais recente, Giddens (2002) emprega o termo modernidade num sentido mais geral, referindo-se "às instituições e modos de

\footnotetext{
${ }^{1}$ Mestre em Geografia pela Universidade de Brasília - Professor do Curso de Geografia e do Curso de Relações Internacionais do Centro Universitário de Brasília.
}

Universitas - Relações Int., Brasília, v. 2, n.2, p. 17-23, jul./dez. 2004 
comportamento estabelecidos pela primeira vez na Europa depois do feudalismo, mas que no século $\mathrm{XX}$ se tornaram mundiais em seu impacto", sendo que a modernidade "pode ser entendida como aproximadamente equivalente ao mundo industrializado, desde que se reconheça que o industrialismo não é a sua única dimensão institucional". O autor argumenta que o mundo industrializado se refere "às relações sociais implicadas no uso generalizado da força material e do maquinário nos processos de produção", havendo uma segunda dimensão institucional que é o capitalismo, definido como "sistema de produção de mercadorias que envolve tanto mercados competitivos de produtos quanto a mercantilização da força de trabalho". Essas duas dimensões distinguem-se das instituições de vigilância, base da força organizacional e da vida social moderna. Segundo Giddens, a vigilância se refere "ao controle e à supervisão de populações submissas ou uso da informação para coordenar atividades sociais" e deve ser separada do controle dos meios de violência que desencadearam a "industrialização da guerra".

Giddens afirma que a modernidade produz certas formas sociais distintas sendo a de maior importância o Estado-nação, entidade sociopolítica que desenvolve-se como parte de um sistema mais amplo de Estados-nações que hoje atingiu um caráter global, e que contrasta com a maioria dos tipos de ordem tradicional. Assim, o Estado-nação "tem formas muito específicas de territorialidade e capacidade de vigilância, e monopoliza o controle efetivo sobre os meios de violência".

$\mathrm{Na}$ perspectiva do capitalismo histórico, Wallerstein (2002) resgata que há cerca de meio século atrás, "moderno" tinha duas conotações muito claras, sendo uma positiva-vanguardista, e outra com característica mais antagônica do que afirmativa. Na conotação positiva-vanguardista, a modernidade era material em sua forma e estava inserida "no contexto conceitual do progresso tecnológico supostamente infindável e, portanto, da constante inovação". Para o autor, "essa modernidade era necessariamente fugaz, pois o que é moderno hoje será ultrapassado amanhã". Na conotação antagônica, "ser moderno significava ser antimedieval, uma antinomia na qual o

Universitas - Relações Int., Brasília, v. 2, n.2, p. 17-23, jul./dez. 2004 
conceito de medieval representava acanhamento mental, dogmatismo e, sobretudo, as restrições da autoridade”. Significava ainda o triunfo da liberdade humana contra "as forças do mal e da ignorância", e uma trajetória de progresso "tão inevitável quanto a do avanço tecnológico" ou "o triunfo da humanidade sobre si mesma, ou sobre os privilegiados". Assumia-se a modernidade "como libertação, da democracia real (o governo do povo em contraposição ao da aristocracia) da realização humana". Assim, "esta modernidade da libertação não era fugaz, era eterna. Tendo sido alcançada, jamais se deveria abrir mão dela".

Harvey (1996) cita Habermas para usar o conceito de "projeto de modernidade" que teria entrado em foco durante o século XVIII, embora o termo "moderno" tivesse uma história bem mais antiga. Esse projeto equivalia a um extraordinário esforço intelectual dos pensadores iluministas "para desenvolver a ciência objetiva, a moralidade e a lei universais e a arte autônoma nos termos de suas próprias lógicas internas", ou seja, a idéia era "usar o acúmulo de conhecimento gerado por muitas pessoas trabalhando livre e criativamente em busca da emancipação humana e do enriquecimento da vida diária". Desta forma, o pensamento iluminista abraçou a idéia de progresso em que "o desenvolvimento de forças racionais de organização social e de modos racionais de pensamento prometia a libertação das irracionalidades do mito, da religião, da superstição, liberação do uso arbitrário do poder, bem como do lado sombrio de nossa própria natureza humana".

A partir deste "esforço de compreensão" do que é a modernidade, passamos à sua discussão. Para Giddens (1991), uma característica marcante da modernidade é o seu dinamismo, derivado de três fontes dominantes: a separação entre tempo espaço, o desenvolvimento de mecanismos de desencaixe e a apropriação reflexiva do conhecimento.

A separação entre tempo e espaço fomenta relações entre indivíduos, grupos ou instituições ausentes, em que "os locais são completamente penetrados e moldados em termos de influências sociais bem distantes deles". Santos (1997) faz menção a emergência de um meio técnico, com o surgimento de um espaço mecanizado e 
artificializado, onde "os tempos sociais tendem a se superpor e contrapor aos tempos naturais", como também "as motivações de uso dos sistemas técnicos são crescentemente estranhas às lógicas locais e mesmo nacionais" presidida pela razão do comércio. O autor afirma ainda que a união da ciência, da técnica e da informação no período atual vem culminando em meio técnico-científico-informacional, sob a égide de um mercado global, onde "atores hegemônicos, armados com uma informação adequada, servem-se de todas as redes e se utilizam de todos os territórios" transformando os territórios nacionais em um "espaço nacional da economia internacional".

Argumentando sobre a crise do fordismo e o surgimento de um novo período em que o capitalismo assume a forma de "acumulação flexível", Harvey (1996) afirma que atualmente vem ocorrendo uma mudança abissal nas práticas culturais e político-econômicas, mudança esta "vinculada a emergência de novas maneiras pelas quais experimentamos o tempo e o espaço". Além da flexibilidade dos processos e dos mercados de trabalho, dos produtos e padrões de consumo, das inovações comerciais, tecnológicas e organizacionais, a "acumulação flexível" se apóia na "compressão espaço-tempo" no mundo capitalista, onde "os horizontes temporais da tomada de decisões privada e pública se estreitaram, enquanto a comunicação via satélite e a queda dos custos de transporte possibilitaram cada vez mais a difusão imediata dessas decisões num espaço mais amplo e variado".

Giddens (1991) afirma que a separação entre tempo e espaço é a condição principal para o processo de desencaixe das instituições sociais. O autor refere-se a "desencaixe" como "o deslocamento das relações sociais de contextos locais de interação e sua reestruturação através de extensões indefinidas de tempo-espaço", fenômeno que "serve para abrir múltiplas possibilidades de mudança liberando das restrições dos hábitos e das práticas locais". Giddens (1991) distingue dois tipos de mecanismos de desencaixe envolvidos no desenvolvimento das instituições sociais modernas, que compreendem sistemas abstratos: "fichas simbólicas" e "sistemas especializados". As fichas simbólicas "são meios de troca que têm um valor padrão" de forma intercambiável, cujo principal exemplo é o dinheiro. Ainda segundo Giddens (2002), os

Universitas - Relações Int., Brasília, v. 2, n.2, p. 17-23, jul./dez. 2004 
sistemas especializados "dispõem de modos de conhecimento técnico que têm validade independente dos praticantes e dos clientes que fazem uso deles" e "penetram em todos os aspectos da vida social nas condições de modernidade", isto pode ser exemplificado desde os alimentos que comemos, aos prédios que habitamos ou aos transportes que usamos. Assim os sistemas especializados "não se limitam às áreas tecnológicas mas estendem-se às relações sociais e às intimidades do eu". Estes sistemas especializados dependem essencialmente da "confiança", definida por Giddens (1991) como "crença na credibilidade de uma pessoa ou sistema, tendo em vista um dado conjunto de resultados ou eventos, em que essa crença expressa uma fé na probidade ou amor de um outro, ou na correção de princípios abstratos (conhecimento técnico)". A confiança pressupõe consciência das circunstâncias de risco.

No que tange à apropriação reflexiva do conhecimento, Giddens (1991) explica que, com o advento da modernidade, "ela foi introduzida na própria base da reprodução do sistema, de forma que o pensamento e a ação estão constantemente refratados entre si" e a "rotinização da vida cotidiana não tem nenhuma conexão intrínseca com o passado". O autor classifica esta perspectiva como perturbadora "pois quando as reivindicações da razão substituíram as da tradição, elas pareciam oferecer uma sensação de certeza maior do que a que era propiciada anteriormente", mas "estamos em grande parte num mundo que é inteiramente constituído através de conhecimento reflexivamente aplicado, mas onde, ao mesmo tempo, não podemos nunca estar seguros de que qualquer elemento dado deste conhecimento não será revisado". Para Morin (1999), atualmente os caminhos conduzem em direção "à pesquisa de uma razão aberta, e não mais de uma razão fechada nos princípios da lógica clássica". Assim, o problema atual "não é o de substituir a certeza pela incerteza, a separação pela inseparabilidade, mas trata-se de saber como vamos fazer para dialogar entre certeza e incerteza, separação e inseparabilidade".

Voltando a Giddens (1991), o conhecimento reflexivamente aplicado à atividade social é filtrado por quatro conjuntos de fatores, como o "poder diferencial", em que alguns indivíduos ou grupos estão

Universitas - Relações Int., Brasília, v. 2, n.2, p. 17-23, jul./dez. 2004 
mais aptos à apropriação de conhecimento especializado do que outros; o "papel dos valores" em que os valores e o conhecimento empírico se vinculam através de influências mútuas; $\mathrm{O}$ "impacto das conseqüências não-pretendidas" em que o conhecimento sobre a vida social transcende as intenções daqueles que o aplicam para fins transformativos; e "a circulação do conhecimento social na hermenêutica dupla" em que o conhecimento reflexivamente aplicado às condições de reprodução do sistema altera as circunstâncias às quais se referia originariamente.

O contexto da modernidade trouxe a crença no afastamento do lado sombrio da natureza humana, onde, segundo Harvey (1996), as artes e as ciências teriam "o papel de promover o controle das forças naturais e a compreensão do mundo do eu, o progresso moral, a justiça das instituições e mesmo a felicidade dos seres humanos". Em contraposição, a modernidade do século $\mathrm{XX}$ trouxe perspectivas jamais imaginadas sobre formas de extermínio da espécie humana, como as guerras mundiais, a ameaça nuclear química e bacteriológica, a constante eclosão de guerras regionais, a destruição e ameaça de ecossistemas, agressões ao meio ambiente. O século XXI vem apresentando uma continuidade destas perspectivas sombrias, onde mesmo equipamentos pacíficos, como aviões comerciais passam a ser utilizados como armas de guerra, ameaçando e aniquilando inocentes. $\mathrm{O}$ aumento generalizado da violência gera uma perspectiva de medo e desconfiança, acirrando a crise da modernidade. Citando a tese de Horkheimer e Adorno, Harvey (1996) menciona a suspeita de que "o projeto do Iluminismo estava fadado a voltar-se contra si mesmo e transformar a busca da emancipação humana num sistema de opressão universal em nome da libertação humana".

Mesmo a experiência de transformação, a partir de Marx, do pensamento utópico em ciência materialista, buscando a emancipação humana de forma classista, em que a classe trabalhadora, dominada pela moderna sociedade capitalista seria o agente de libertação, falhou em sua implantação real, cuja lógica baseou-se na repressão e no totalitarismo.

Outra crítica em relação à modernidade diz respeito à globalização em suas diversas vertentes, onde, para Santos (2000), há

Universitas - Relações Int., Brasília, v. 2, n.2, p. 17-23, jul./dez. 2004 
um processo de crises sucessivas que alcançam uma dimensão global e estrutural, cuja tentativa de soluções não estruturais, conforme o "interesse de atores hegemônicos" acaba gerando mais crise. Desta forma, "se a única crise que os responsáveis desejam afastar é a crise financeira e não qualquer outra", isto causa "mais aprofundamento da crise real - econômica, social, política, moral - que caracteriza o nosso tempo".

Diante da crise de uma modernidade baseada na crença do progresso linear, nas verdades absolutas e no planejamento racional de ordens sociais ideais, encerramos com a indagação de Wallerstein (2002): O que aconteceu com a modernidade, que não é mais a nossa salvação e tornou-se o nosso demônio?

\section{Referências Bibliográficas}

GIDDENS, Anthony. As Conseqüências da Modernidade. São Paulo: Ed Unesp, 1991, $2^{\text {a }}$ ed.

GIDDENS, Anthony. Modernidade e Identidade. Rio de Janeiro: Jorge Zahar Editor, 2002.

HARVEY, David. Condição Pós-Moderna. São Paulo: Edições Loyola, 1996, $6^{\text {a }}$ ed.

MORIN, Edgar. "Por Uma Reforma do Pensamento". in PENA-

VEGA, Alfredo. NASCIMENTO, Elimar Pinheiro (org). "O Pensar Complexo: Edgar Morin e a Crise da Modernidade". Rio de Janeiro: Garamond, 1999.

SANTOS, Milton. A Natureza do Espaço - Técnica e Tempo Razão e Emoção. São Paulo: Hucitec, 1997.

SANTOS, Milton. Por uma Outra Globalização: Do Pensamento Único à Consciência Universal. São Paulo: Record, 2000.

WALLERSTEIN, Immanuel. Após o Liberalismo: Em Busca da Reconstrução do Mundo. Petrópolis: Editora Vozes, 200297.

Universitas - Relações Int., Brasília, v. 2, n.2, p. 17-23, jul./dez. 2004 